\title{
ミラノ高等技術学校の創設と C.ボイトの建築教育理念について THE FOUNDATION OF ISTITUTO TECNICO SUPERIORE DI MILANO AND
C. BOITO'S PRINCIPLE OF THE ARCHITECTURAL EDUCATION
}

横 手 義 洋*

Yoshihiro YOKOTE

\begin{abstract}
The reform of architectural education in the 19th century originated in architect's rivalry against engineers in the profession of architecture. The predecessor of the present Milan Polytechnic, Istituto tecnico superiore di Milano, was founded as a school of engineer after the unity of Italy, and then was added a special school for "architetto civile" which gives both scientific and artistic culture. This school was the mirror of medievalist C.Boito's radical principle of architectural education. But it just caused the conflict between Istituto tecnico superiore and existing Academy of Art regardless of a dominance of engineer in the profession of architecture.
\end{abstract}

keywords : Italy, Milan, 19th Century, Boito, architectural education イタリア, ミラノ，19世紀，ボイト，建築教育

1. 序

19 世紀におけるイタリア建築を考えるとき、当時急速に発達し てきた科学や工学を無視することはできない。科学技術の発展に伴 いかかては不可能であった新しい建策が実現していったのは周知 のとおりである。ただ、ここで問題としたいのは、建築作品に現れ る技術応用の問題や建築技術発展の経緯ではない。科学技術の発展 が新しい時代の建築を可能にするという認識にはじまり、新しい時 代にふさわしい建築家 architetto の養成へといたる建築教育制度の 問題である。建築教育制度が近代科学の台頭に応答していたかとい う点では、国家統一の遅れたイタリアは他のヨーロッパ諸国に一歩 遅れをとっていた。そうであるがゆえに、統一を機に、ドイツ、ス イス、フランスに做った建築教育改革が北イタリアにおいて大々的 に行われたのである。こうした科学技術の台頭に準じた制度改革の 成果は、トリノとミラノに誕生した技師養成機関に見出すことがで きる。だが、技師の養成機関内に建築学部を設けたという点では、 ミラノ高等技術学校 ${ }^{1}$ (現在のミラノ工科大学) がイタリアで最初の 事例であった ${ }^{2}$ この先進性においてミラノの建築教育を考察する意 味が出てくる。むろん既往研究では、高等技術学校に関して O.セル ヴァフォルタ、V.フォンターナ等が、美術アカデミーに関して G. リ. ッチがそれぞれの建築教育制度の変容を丁密に追っている3。このよ

うな成果を踏まえ、本論はミラノ高等技術学校における建築教育を 単一機関という枠組みを超えた視角で検証し、とくにミラノ、イタ リアの建築教育全体の流れからの意味づけ、さらに、教育科目構成 の分析から立証される建築思潮との関連に焦点を当てるものである。

\section{2. 北イタリアにおける国家統一前の建築教育 ${ }^{4}$}

18 世紀の後半から、建築教育は美術アカデミーにおいて、絵画、 彫刻といった芸術と並ぶ講座として統一的に教授されてきた。だが、 美術アカデミーで建築を学びさえすれば、そのまま実社会において 建築職和約束されるかというとそうではなかったようである。少な くとも 1850 年代のロンバルディア、ヴェネト地方において、合 法的な建築職への道は、原則として大学の数学科を卒業した者に限 られており、美術アカデミー卒の者でも相当優秀な成績を納めなけ ればならなかったといゔ。1858年の「B-o.」と署名された論文 は、そのことを伝える資料のひとつである。

「ロンバルディアやヴェネト地方において、数学を卒業していな い者や、職業資格`を取っていない者は、法律の上では建築職に就 くことはできない。職業資格を取るためには、後期中等学校、あ るいは王立学校の教育課程を経る必要がある。たとえば、数学に 関しては大学において、建築に関してはアカデミーにおいて。そ

* 東京大学大学院工学系研究科建築学専攻 大学院生・修士 (工学) 日本学術振興会特別研究員
Graduate Student, Dept. of Architecture, Faculty of Engineering, Univ. of Tokyo, M. Eng.

Research Fellow of the Japan Society for the Promotion of Science 


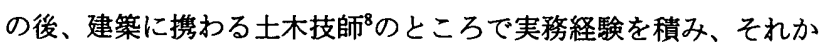
ら関俰当局で職業資格試験を受けるのである。」9

以上から、当時建築職に就くことに技術的教養と経験が求められ ていたことは明らかである。芸術家に属する従前の建築家のあり方 は、限りなく構造や設備を専門とする技師寄りに追いやられていた ようだ。この事情を裏づける根拠は、建築ジャーナリズム自体にも 探すことができる。ミラノでは国家統一前から建築教育に関する議 論が活発に行われており、1839 年に雑誌『II Politecnico』、18 53 年には『Giornale dell'Ingegnere Architetto e Agronomo』誌が創刊 された。前者は人文科学部門と技術部門、つまり文芸と科学を統一 的に扱う建築雑誌を目指していた。一方、後者はタイトルにも示さ れているように技師 - 建築家そして農学者に共通の雑誌である。両 雑誌ともに、建築の領域がもはや芸術にとどまらず工学的分野との 境界線を瞹昧にしていったことを示すものである。

ミラノ工科大学教授 G.リッチの研究によれば、すでに 1805 年 11 月時点のミラノの職業資格規定において、技師 ingegnere と建築 家 architetto の区別は曖昧なものになっており、ミラノ美術アカデミ 一教授 G.ボッシさえ建築を「工学的な計画の分野」であることを認 めていたという ${ }^{10}$ 。建築の職業資格が必ずしも芸術教育を経る必要が ないとすれば、美術アカデミーの立場はなくなってしまう。このこ とは当然ながら、美術アカデミーによる職業資格制度への介入を促 すものとなっていく。1843 年には、大学の卒業者に対して、ミ ラノかヴェネツィアの美術アカデミーに設けられた 2 年間の建築課 程に通うことが義務つけられ、そこにおいて「建築技師 architetto civile」 ${ }^{11}$ の職業資格試験が行われるようになった。ここに登場する 建築技師は、大学で工学的教養を学んだ者に対して与えられる新し い建築家の資格を示すが、少なくともその名称において、芸術教育 だけを学んだ「建築家 architetto」との区分をはっきりと見てとれる。 1852 年になると当時の中央政府ウィーンで教育改革の論議がな され、ヴェネッィアとミラノのアカデミーもこの動きへの追随を余 儀なくされる。ヴェネツィアでは P.セルヴァーティコ(Pietro Selvatico, 1803-1880)が、改革を強力に推し進め、アカデミーで芸術教育を受け ていない大学卒の技師のために建築史の講座を持った。しかし、果 たしてこれらが功を奏したのか。

再び「B-o.」の論文を見てみよう。

「建婑装飾の学校は存在していない。透視図法は図形幾何学の付 録としてさえ扱われない。(․) 要するに、学生は（ローマの様式 を含め) あらゆる様式、装飾、配置、適性、建築構成、透視図に 無知であるだけでなく、簡単な投影図も描くことができず、壁、 アーチ、柱、屋根、その他が適切に考えられたごく単純な建物も 構想することができないまま、大学を卒業するのである。」12

確かに、建築職に携わるようになった技師たちに建築の芸術面を 習得させるために、大学卒業後、美術アカデミーに 2 年間通うこと が義務づけられた。だが、この教育の不備をわずか 2 年間で補うに は無理があった。さらに、土木技師の下での実習期間についても、 あまりに局所的な専門分野に携わるために決して有効とは言えなか ったようである。また、建築職に就けるようになるためは通常 8 年 から 15 年間を要したとされるが、これもあまりにも長過ぎた。数 学者、土木技師の厳密に過ぎる分析に遠回りせず、もっと総合的で
柔軟な建築教育が望まれていたのだった。そして、先の「B-o.」の 論文『建築技師のための新しい教育制度の提案』は、まさにこうし た問題の解決に取り組んだものであった。ここにも「建築家」ではな く、わざわざ建築技師」と書かれている。国家統一後におけるミラ ノの新制度は、建築技師の専門的な養成の実現を主題とし、それは 大学でもなく、アカデミーでもない、第三の組織（高等技術学校の 建勧学部）において養成されることになる。赛を言うと、ヴェネッ ィアのアカデミーにおいてセルヴァーティコの弟子であった C.ボイ ト(Camillo Boito, 1836-1914)こそが、「B-o.」その人であった"13。彼は 1859 年ヴェネッィアからミラノへ移り、教育改革を通して自ら の建築理念を実践してゆくのである。

\section{3.ミラノ高等技街学校の誕生とボイトの建築理念}

ロンバルディアがオーストリアから解放された 1859 年は、制 度面において大きな変化がもたらされる節目の年となった。ミラノ 高等技術学校は、1859年11月13 日公立教育法（通称カザー ティ法) ${ }^{14}$ 第 310 条によって創案され、1862年11月13日の 䡃令によって具体化した。学校の創立は 1863 年である。高等技 術学校成立に主導的な役割を果たしたのは、1861-62 年に文 部省で事務局長を務めた F.ブリオスキ(Francesco Brioschi, 1824-1897) 教授で、実際に力学を教授しながら㱛するまで初代学長を務めた ${ }^{15}$ 。 しかし、高等技術学校の初年度（1863-6 4 年度）は、まだ土 木技師、機械技師のための 2 学部しかなく、建築技師を盖成する学 部を備えてはいなかった。そして、創立の 2 年後、1865 年 9 月 3 日の䡃令によって、建築技師の資格授与を認可するために学則第 14 条が次のように改められる。

「先の䡃令はミラノ高等技術学校に建築技師の資格授与を認可す るもので、本年にこの学部の最初の二つの講座が開始される。初 等建築装飾、幾何意匠の試験以外の認可条件は、他の 2 学部（土 木工学、機械工学) と同様のものであり、同様に、理論実践教育 の諸々のものも 3 学部に共通する。」（括弧内は引用者による） 16 当時イタリアにおける他の地方では、大学が建築技師の資格を水 力技師の資格と合わせて認めたり、法的に認められた建築家のもと で実務を行って建築技師の資格が得られるところもあるなど、建築 技師の義成にはまだ十分な対応がとれておらず、その必然として建 築技師が工学技師と区別がつかない状況であった。本学はこの問題 を解決するために、建築技師の資格を専門的に授与する機関であっ た。この新しい職能を養成する専門機関はイタリアにおいてミラノ の高等技術学校が唯一のものだった。科学的な教育と芸術的な教育 の両方を可能にする建築学部は、美術アカデミーのボイトと、高等 技術学校のブリオスキの合意によって実現された。その教育は、高 等技術学校で教えられる技術教育と、美術アカデミーで教えられる 芸術教育の両方から恩恵を得るものである。さらに、既存の教育機 関を利用することで、何ら特別な出費なしに近代建築の進展が要請 する学校の創設が可能になり、これによってきわめて重要な建築技 師の地位が向上するというのが発案者たちのねらいであった。むろ ん、これは新しい建築学校の設置に対して政府の許可を得やすくす る戦略でもあっただろう。

こうして、建設工学から建築史までを幅広く備えた近代建築学校 
は、制度の上では高等技術学校内の機関であるにもかかわらず、そ の教育は高等技術学校と美術アカデミーの一部分ずつを統合させた ものだった。ところで、科学と芸術の統合という主題はボイトの建 築論においても重要な役割を果たしているが、このことは単なる偶 然ではない。当時、建築批評あるいは建築論と建築教育批評は密接 な結びつきを持っていたからである。例えば、1860年にボイト

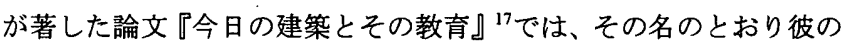
建築思想と建築教育理念が並行しており、「今日のイタリアには建 築も建築教育も存在しない. ${ }^{18}$ という痛烈な批判が浴びせられている。 このように、建築批評が建築教育批評と重ねられる傾向は、185

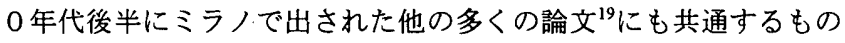
である。さて、科学と芸術の統合という主題に話を戻すと、ボイト は建築論において、建築を構成する要素を組成的な部分（オルガニ ズモ）と象徵的な部分（シンボリズモ）に分け、両者が理想的に統 合されてはじめて本当の近代建築が立ち現れると考えていた。

「美や表現は、二つの部分（オルガニズモ、シンボリズモ）の統 一からもたらされる。したがって、二つの部分は建築芸術の一つ の様式というべき統合体を形成する。」(括弧内は引用者による) ${ }^{20}$ ヘーゲル思想を借りたこの建築の二元論が明らかなかたちで発表 されたのが、高等技術学校に建筑学部が設置される前年の1865 年だったことを考えると、ボイトの建築論とミラノの建築教育改革 との接点について、もつと掘り下げてみる必要がありそうである。

まずは、具体的に教育科目の構成を見てみよう。高等技術学校の 建築学部は 3 年制 ${ }^{21}$ で、1866-67 年度から授業が行われた。授

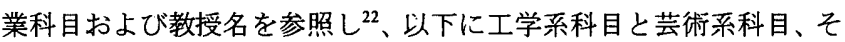
して、ボイト自身が教えた講義科目を区別してみる。

【1 年次】

工学系(Meccanica razionale, Topografia, Geognosia e mineralogia applicata, Disegno-applicazioni della geometria descrittiva) 芸術系(Elementi di disegno di figura, Copia di ornamenti; acquerello) ボイト(Lezioni orali sulla storia dell'architettura; sulla convenevolezza e comodità architettonica; sugli stili, studi pratici sulle dette materie)

【 2 年次】

工学系(Fisica tecnologica, Scienza delle costruzioni-costruzioni civili, Disegno di costruzione, Esercizi pratici di topografia e disegno topografico)

芸術系(Copia e composizione di ornamenti, Disegno di prospettiva; acquarello a colori)

ボイト(Lezioni orali sulla convenevolezza e comodità architettonica; sugli stili; studi pratici sulle dette materie, Rilievi e restauri di edifici)

【 3 年次】

工学系(Elementi di diritto amministrativo e di giurisprudenza agricola, Disegno di costruzioni)

芸術系(Copia e composizione di ormamenti, Decorazione ornamentale interna degli edifici-suppellettili ed arredi, Modellazione in creta degli ornati architettonici, Disegno di prospettiva; acquarello a colori)
ボイト(Lezioni orali sugli stili; sull'architettura più conveniente alla società odierna de all'Italia; studi pratici sulle dette materie composizione di progetti, Rilievi e restauri di edifici)

工学系科目については、土木技師、機械技師の学部で行われてい るものとまったく共通のものであり、芸術系科目は美術アカデミー 教授によるものである。だが、1865年より高等技術学校建築学 部長と美術アカデミー建築学校長を兼ねるボイトの講義科目、1 年 次における「建築史；建築の適性および快適性について；様式につ いて；以上に関する赛用演習小、2 年次における「建築の適性および 快適性について；様式について；以上に関する実用演習」、「建物の 実測および修復」、3 年次における「様式について; 現在の社会、イ タリアによりふさわしい建築について；以上に関する実用演習 - 設 計製図」、建物の実測および修復」は特別な存在であるように思わ れる。実に、この建築学部の教育科目の全体は 1858 年の「B-o.」 の論文『建築技師のための新しい教育制度の提案』、そして1861 年のボイトの論文『建築技師のための新しい教育制度の必要性につ いて』23の内容を非常に色濃く反映したものであることがわかるのだ が、そのなかでボイトは建築教育を 3 つの部分に分けて論じている。 最初が、建築芸術（歴史、修復、設計）、次に科学技術の科目、最後 に意匠と装飾の科目である。そして、先ほど示した授業科目リスト を見ると、まさしく高等技術学校の建築学部においては、第 1 番目 の内容をボイトが担当しており、第 2 番目を高等技術学校の教授が、 第 3 番目を美術アカデミーの教授が担当しているのである。さらに、 このことを先に言及したボイトによる建築の二元論との関連におい て評価するなら、オルガニズモが科学技術の科目、シンボリズモが 意匠・装飾の科目に相当する。そして、おそらくボイト自身が担当 した第 1 番目の建築芸術こそが、前 2 者の理想的統合体を目指寸要 の部分、もっと言えば、ボイトが探求している近代建築の「一つの 様式」へと直結する部分として機能すると考えられるのである。建 築芸術の教育内容についてボイトの記述を参照してみよう。

「(建築芸術の) 教授は、すべての建築史を簡潔に概説することか ら始め、時代を追うて、各様式の特徴、ある様式から別なものへ の派生、それぞれの影響関係を取り上げていかなければなら゙ない だろう。(‥)そうした概論をわずかの講義で終え、各様式に関す る詳細かつ十分な論議を行わなければならないだろう。その研究 は、われわれ現代人にとって有効な教訓となりうる。だがその前 に、建築の適性および快適性に関する指導と、それに並行するか たちでもっとも理性的で適切かつ経済的な建物の配置に関する演 習が行われなければならないだろう。それによって、細心綿密に 建物の安定性の要求に応じることができ、また美の要求にも留意 することができるのである。(…) 2 年次には、ギリシア、ローマ、 15 世紀、16 世紀の様式に関する美学史を教授すべきだろう。 そして、この講義とともにルネッサンス様式をはじめとする様式 の実践課題を行う。(…) しかし、 3 年次にはもう少し時代を遡り、 ローマ衰退後のビザンチン、バジリカ、コモ、アラブ、尖頭式の 建築を扱う。(…)そして、中世末期のイタリア建築へといたるが、 $(\cdots)$ ここでとくに教授は意匠や設計において学生を重点的に指 導するべきである。というのは、確かであるかどうかはわからな 
いが、おそらくピサ、フィレンツェ、ヴェネツィア、コモ、シチ リアの様式から、われわれの近代建築が基づく原理、少なくとも それを示す特徴がもたらされるからである。これらすべての講座 は、現代、そしてイタリアにふさわしい建築に関する $(\cdots)$ いく つかの研究で完成する。」 24

ボイトの講義は、建筑史、様式の概論からはじまり、古典および ルネッサンス様式の設計を経て、最終的にイタリア中世建築の実測 および設計へと展開する。3 年次に行われる「様式について ; 現在 の社会、イタリアによりふさわしい建築について ; 以上に関する実 用演習 - 設計製図」は、カリキュラムの中でもっとも比重の高いも のとなっている。この事実は、ボイトが熱心に取り組んでいた新し いイタリアの建築の模索が、将来の建築家の養成過程にも直接的に 影響を及ぼていることを示す。そして、もっとも興味深いのは、 このイタリアにふさわしい建築が中世建築であることが講義の展開 において明らかになっている点である。すなわち、2 年次において $15 、 16$ 世紀建築を取り扱いながら、完成期である 3 年次にまで わざわざ中世建築研究を取っておかなければならない。ここにも、 ボイトの支持していた建築における中世主義の理想 25 と、彼が理想と する建築教育のあり方が重ねあわされる。

また、中世主義を標榜するボイトの講義は、歴史、修復、設計の 3 要素から成り立っているが、それぞれは独立して機能するもので はない。建築史概論は直ちに詳細な様式論へと移行し、現実性をも って論じられる様式論は設計演習に直結している。その際、「建築の 適性および快適性について」と「実用演習」が、構造と美の要求の両方 を満足させる点において重要科目であることをボイトは先に伝えて いた。それらは明らかにオルガニズモとシンボリズモの統合に配慮 した科目であることを示している。このように、ボイトが教える歴 史は建築の二元論を介すことによって現代における批判性を獲得し、 設計演習に不可欠の講義となりえているのである。同じ構造はボイ トが各論文のなかで歴史記述を行う際にも健在で、ギリシア建築か ら現代までの重要な建築にオルガニズモとシンボリズモのどちらが 優勢だったかを論じるのである ${ }^{26}$ ○れでは、修復についてはどうだ ろうか。 $2-3$ 年次に行われる「建物の実測および修復」は、ヨー ロッパにおける最初の建築修復講座であるが、この講座には、ボイ ト自身のヴェネツィアにおける S.ドナート聖堂、コモにおける S.ア ボンディオ聖堂の修復経験が生かされた。言うまでもなくこれらの 聖堂は北イタリアの中世建築であるが、ボイトが修復の講義として それらを選択した理由は、十分に観察可能な建築は身近なものでな

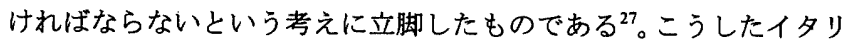
ア中世建築の修復におけるボイトの態度というのは、さまざまな研

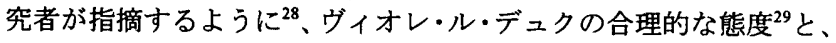

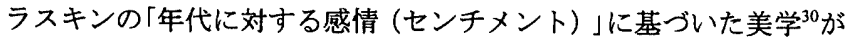
並存するものであった。前者は建物に対する現実的かつ積極的な修 復へ、後者はとりわけ中世建築に顕著な絵画的要素や色彩の保存へ ボイトを導いた。そして、ボイトの修復論における両者の並存、そ して葛藤こそが、煎じ詰めればやはりオルガニズモとシンボリズモ 両者の統合という悲願へ帰着するのである。このように、歴史、修 復、設計が三位一体となったボイトの講義はオルガニズモとシンボ リズモの調和をめざす試行過程であり、同時に工学系科目と芸術系
科目の理想的調停の科目となりえている。この建築学部はまさしく 1850 年代後半からボイトが構想してきた建築教育理念の具体的 実践なのであり、さらに将来の建築家たちを通して自らの建築理念 を社会的にも実現させようとした機関であったと言うことができる のではないか。

\section{4. 世紀末の建築家の現状}

ミラノに実現した理想的な建築学校がイタリアにおいて先進のも のであったことを確認させてくれるのが、1872 年にミラノで行 われた第 1 回イタリア技師・建築家会議である。この全国会議では、 建築家という職能において科学技術の果たす役割の重要さが確認さ れ、高等技術学校や技師養成機関のない地方では美術アカデミーに おいて工学系の教育が取り入れられるように提案がなされている31。 だが、カザーティ法第 55 条を施行する 1876 年 10 月 8 日の䡃 令によって、ついに美術アカデミーが建築家を輩出することが制度 の上では不可能となった。すなわち、美術アカデミーは法的に建物 を建てる資格を持たない「建築意匠の教師」 ${ }^{32}$ のみを養成する場とな り、全国的に技師養成機関が合法的な建築家（すなわち建築技師） を独占的に輩出することになったのである。原則として、美術アカ デミー卒の学生はただの意匠家 disegnatore になるか、法的に認めら れた建築技師の名前の下で働くしかなかった。

統一後のミラノにおいては、高等技術学校の建築学部を立ち上げ ながらも、なお美術アカデミーの建築学校も並存していたため、美 術アカデミーの存在が宙に浮くようになるのは当然の成り行きだっ た。美術アカデミーにおける建築教育は世紀末にかけてますますそ の役割を消失していった ${ }^{33}$ 。もっとも、高等技術学校に通わない美術 アカデミーの学生も、最終的に高等技術学校において工学系科目の 試験に合格すれば建築技師の資格が与えられたようだ34。この救済措 置が、もともとは美術アカデミー側に身を置いていたボイトによる 温情に発したものなのかどうかを確認することはできない。ただ、 ボイトは世紀末の建築家の現状に芸術的教養が著しく欠けているこ とを愳念していたのは確かである。ボイトによる論考『イタリアに おける建築家の現状』 ${ }^{35} に は$ 次のように書かれている。

「建築の多方面で熟達した建築意匠の教師の方が、技師義成機関 において正式に建築技師の資格を与えられた学生たちよりもずっ と優秀な建築家になるということを真実をもって明言しなければ ならない。」 ${ }^{36}$

一見すると自らの建築教育改革批判とも受けとれるこの言葉は、 高等技術学校の建築教育を美術アカデミー側へ寄せようとする気持 ちに裏打ちされている。そして、どうやらこの姿勢は、ボイトの教 育改革において息のかからなかった大学、高等技術学校工学部を出 た技師の存在から来ているようだ。

「一方に技師、他方に建築家と言っても無駄である。いや、イタ リアにおいてその区別は判然としないか、ロンバルディアやピエ モンテといった地方では、モニュメントや建築物を造るときであ ってもむしろ技師の方が好まれているのである。多くの資産家た ちは、郊外の別荘、墓地の礼拝堂、都市住宅を建てようとすると きに、農村の建物に従事し、農地を測量し、桑の木を数え、町の 建物の日常管理に備え、会計士とともに経営に専念する自分たち 
の技師に依頼しなければ、この技師が傷つくとでも思っているの だろう。ときには、自分たちの住まいの装飾や家具の指揮にいた るまで、その技師に迷わず任せる。そして、技師は $(\cdots)$ 愛想良 く従うのである。」 ${ }^{37}$

そして、論は次のように締めくくられる。

「実践と理論的な基礎知識の両方で、科学には暗いが芸術に明る い建築家は、賞賛をもってほぼすべての公共建築をつくることが でき、全く例外的な場合にだけ、特別な建物について他人の知恵 や技師の助けを求める必要がある。しかし、科学には明るいが芸 術に暗い免許制の建築家は、誰の助けも借りずにすべての建物を 建てるだろう。だが、そのすべては醜いものであろうっ」 ${ }^{38}$

以上からは、ロンバルディアにおける建築職において、数の上で は技師が圧倒的に優勢であったことに対するボイトの苛立ちが読み とれる。理想的な建筑教育が高等技術学校だけで実現したといって も、それに無関係な技師の造る建物が現実の都市を覆ってゆくので ある。そもそも、ボイト等の策定した理想的な建築教育が工学的教 養を受け入れるものであったのだから、時代の趨勢として建築職に おける技師の立場が摇るごうはずがなかった。

こうして、ミラノ高等技術学校に建築学部が開設されて約 20 年 後、主な支持者だったボイトまでが芸術教育の強化を主張せざるを えなくなったのである。同様の認識はブリオスキにも認められる ${ }^{39} 。$ 建築家にとって工学系の科目は必要最小限に减らさなければならな いというのが、両者の一致した見解であった。こうして、高等技術 学校でさえ美術アカデミーのすべての芸術教育を利用しなければな らないという提案がなされる。そして、全国的には美術アカデミー に建築家の資格授与の権限を戻すか、あるいはまったく独立した新 機関をつくるかという議論がなされた。とはいえ、1880年代に 行われたこうした議論が、建築職における土木技師の優勢に菌止め をかけ、建築家の地位の復権をねらったものであることを忘れては ならない。したがって、大局的には建築教育が再び芸術教育のみに 回帰することはなかった ${ }^{40}$ こうして、ミラノにおいては 20 世紀初 頭まで高等技術学校と美術アカデミーが建築教育の二極であったが、 その比重は徐々に高等技術学校へ移っていった。1926 年に全国 の美術アカデミーの建築学校を廃止するナーヴァ法、1932 年に は建築教育を大学制度として整理する法規が定められだ1。こうして 1933 年、新制ミラノ工科大学建築学部の誕生によって、半世紀 に及ぶ建築教育の二重体制は幕を閉じた。

\section{5. 結語}

19 世紀後半の建築教育の歷史は、工学的教養を備える技師の台 頭によって危機に陷った建築家の地位をいかに取り戻すかという試 行の連続そのものであった。このなかで、ミラノのボイトは近代的 な建築家のあり方を建築技師と定め、高等技術学校の建築学部を通 じて理想的な教育制度を完成させた。この教育制度改革は、二つの 側面から評価できるのではないだろうか。まず、高等技術学校の教 育機関それ自体としては、紛れもなくイタリアにおいて先鋭的な教 育思想を反映したものであり、とくに中世主義の主唱者であったボ イトの理想を、将来の建築家の養成を通じて具体化するという点で はきわめて操作的なイデオロギー装置になりえた。実際、ボイトの
息がかかった建築家が世紀末そして 20 世紀初頭に活躍している。 だが、高等技術学校の成立が建築家の危機的事態を変ええたかとい うと、結局のところ高等技術学校の建築教育は既存の美術アカデミ 一の教育と並行し競合こそすれ、その傍らで技師が実質的な建築家 として大勢を占める状況に何ら有効な手をくだせなかった。ひとつ の組織や制度によって建築家の地位が復権できるほど、事情は単純 なものではなかったからである。この教育改革は工学的教養を備え る理想的な建築家像には応答していたが、そうであるがゆえに技師 と建築家の混乱をくい止めるどころか、逆にそれを助長する特殊な 建築家の資格（建築技師）、を誕生させるにとどまったのだった。

\section{註}

1 創設時の正式名称 Istituto tecnico superiore di Milano の訳。ただ、実 際には創設”当初から「ポリテクニコPolitecnico」と呼ばれており、 1937 年に正式名称が Politecnico di Milano と改められた。 Selvaforta, $\mathrm{O}$. : La formazione dẹ tecnici del progetto nella Milano della seconda metà dell'ottocento, Mozzarelli, C. : Milano fin de siècle e il caso Bagatti Valsecchi, Guerini e Assọciati, Milano, 1991, p.219, n.3 を 参照。

2 少なくとも創立時において、二つの技師盖成学校 Scuola di applicazione a Torino と Istituto tecnico superiore di Milanoはその性格 を異なるものとし、前者はパリの土木学校に、後者はドイツの工 科大学に近いものであった。言い換えれば、前者が土木技師を専 門的に養成する学校であるのに対し、後者は「ポリテクニコ」とい う俗称が示すがごとく、土木技師、機械技師、化学技師、建築技 師の羔成に必要な多様な技術教育を備えることを目指していた。

Dei Poli, A. et al. : Cent'anni di vita del Politecnico attraverso la lettura dei suoi programmi ordinamenti ed effemeridi, Il centenario del Politecnico di Milano 1863-1963, Milano, 1964, p.137, n.1 を参照。

${ }^{3}$ Selvafolta, O. : La didatticae la ricerca tra il 1863 e il 1914, L'Istituto tecnico superiore di Milano, metodi didattici ed ordinamento interno (1863-1914), Il Politecnico di Milano una scuola di formazione della società industriale 1863-1914, Milano, 1981, pp.87-118

Fontana, V. : Politecnico e sviluppo urbano (1863-1914), La scuola speciale di architettura(1865-1915), Il Politecnico di Milano...op.cit., pp.228-251

日本語論文としては、河上且理 : ジョヴァンニ・ヴィンチェンツ オ・カッペッレッティ研究一新出資料による来日以前の経歷, 日 伊文化研究，第 36 号, pp.32-50, 平成 10 年 3 月が、ミラノ美術了 カデミーにおける建築教育制度に言及している。

${ }^{4}$ 本章での職業資格制度に関する記述は、特別な限定がない場合、 ロンバルディアおよびヴェネト地方全般を対象とする。

${ }^{5}$ professione di architetto あるいは professare architettura

${ }^{6}$ Belski, M.P. : 1860-1918 Milano cresce, Firenze libri, Firenźe, 1995, p.115, n.1

7 原語では patente di libero esercizio

8 原語では ingegnere civile

${ }^{9}$ B-o. : Proposta di un nuovo ordiname nto di studi per gli architetti civili, Giornale dell'Ingegnere Architetto e Agronomo, p.583, 1\$58.11

${ }^{10}$ Ricci; G. : L'architettura all'Acca demia di Belle Arti di Brera Insegnamento e dibattito, Ricci, G. et al. : L'architettúa nelle accademie riformate, Milano, 1992, p.273

11 本用語の正確な定義を記した資料を見つけることはできないが、 芸術的教養のみを備えた従来の建築家 archítetto とは区別して使用 されたと考えられる。「工学的教養を供えた建築家」というのが原 
語のニュアンスにもっとも近い表現であろうが、冗長に過ぎるた め本論では「建䇣技師」と訳した。ただし、その存在がどれだけ土 木技師 ingegnere civile に近づくとはいえ技師 ingegnere ではなく、 あくまでも新しい時代の《建築家 architetto》であることには注意 が必要である。ちなみにイタリアでは architetto と ingegnere の関係 や区分についての研究関心がほとんどで、どういうわけか architetto civile と architetto の厳密な区別について正面から取り上 げた研究者はいない。実際、研究書によっては architetto civile 龺 単に architetto と表記して論じるものさえあり、雨者の区別は文脈 より判断せざるをえないくらいである。

${ }^{12}$ B-o. : op.cit., p. 584

13 「B-0.」がC.ボイトのペンネームであることは、イタリアの研究 者の間では定説である。「B-o.」による論文『Proposta di un nuovo ordiname nto di studi per gli architetti civili』(1858)、ボイトによる論 文『Sulla necessità di un nuovo ordinamento di studi per gli architetti civili』(1861)における建築教育論の共通性から、本論もこれに同意 している。

14 高等技術教育法を制定したミラノ人ガブリオ・カザーティ伯の名 にちなんでこう呼ばれる。

15 1850 年から 1860 年まではパヴィアにおいて力学、建築技 術、水力学を教授した。文部省の事務局長 Segretario Generale della Pubblica Istruzione としての経験は、とくにドイツの教育事情を知 るのに大いに役に立った。

${ }^{16}$ Dei Poli, A. et al. : op.cit., pp.141-142

${ }^{17}$ Boito, C. : L'architettura odierna e l'insegnamento di essa, Giornale dell'Ingegnere Architetto e Agronomo, 1860.6

${ }^{18}$ Ibid., p.269

${ }^{19}$ Magister Comacino : Sull'insegnamento dell'architettura, Giornale dell'Ingegnere Architetto e Agronomo, pp.127-133, 1855.9, Magister Comacino : Utopie nell'insegnamento dell' architettura, Giornale dell'Ingegnere Architetto e Agronomo, pp.283-289, 1855.12, B-o. : Proposta di un nuovo ordinamento di studi per gli architetti civili, cit., pp.583-590, 1858.11

${ }^{20}$ Boito, C. : Revista delle arti belle, Il Politecnico. Parte Letterario-Scientifica, p.104, 1865.1

${ }^{21} 1875-76$ 年度には、 3 年間の専門課程の前に 2 年制の教養 学部が設置され、高等技術学校の教育は 5 年制となる。

${ }^{22}$ Dei Poli, A. et al. : op.cit., p.144

${ }^{23}$ Boito, C. : Sulla necessità di un nuovo ordinamento di studi per gli architetti civili, Giornale dell'Ingegnere Architetto e Agronomo, 1861

${ }^{24}$ Ibid., pp.744-745

${ }^{25}$ ボイトの中世主義については、拙稿：イタリア中世主義における 「ロンバルディア建築」の歴史的正当性について，日本建筑学会 計画系論文集，第 530 号，pp.243-247，2000 年 4 月を参照。

${ }^{26}$ Boito, C. : Revista delle arti belle, op.cit., 1865, L'architettura nella nuova Italia, Nuova Antologia, XIX, pp.755-773, Sullo stile futuro dell'architetura italiana, Architettura del Medio Evo in Italia, Hoepli, Milano, 1880, pp.V-XLVI 等を参照。

27 「建物は死骸のように、いや、生身のごとく観察や実験にその身 をさらすことができる。あるモニュメントを長い間凝視する者の 目の前で、それは生き返り、動き出し、語るのである。涂形、葉 飾り、荒石:あらゆる部分が毎回少しずつ何かを語り、少なくとも 過去の状況の一部分を告白するのである。真の研究者の呼びかけ が聞こえないそ:ニュメント、無口なモニュメントは稀である。」 Boito, C. : Sullo stîle futuro dell'architettura italiana, op.cit., p.IX

${ }^{28}$ Ceschi, C. : Teoria e sioria del restauro, Mario Bulzoni Editore, Roma, 1970, p.108, Bellini, A. : Boito tra Viollet-le-Duc e Ruskin?, Grimondi,
A. et.al. : Omaggio a Camillo Boito, Franco Angeli, Milano, 1991, pp.159-167 等を参照。

${ }^{29}$ 拙稿:「様式的修復」に見るイタリア中世主義の限界について，日 本建築学会計画系論文集, 第 533 号, pp.245-250，2000 年 7 月

30 「あらゆる色調、あらゆる染み、年代一偉大な画家、偉大な調整 者一が建物を染めた色を敬う」Boito, C. : Relazione sul progetto di restauro per la basilica di S.Maria e Donato in Murano, Giornale dell'Ingegnere Architetto e Agronomo, p.76, 1861.9

ラスキンの保存理念に関しては、鈴木博之 : ヴィクトリアン・ゴ シック末期の建築保存論 その 2 . ジョン・ラスキンの保存理念, 日本建築学会論文報告集, 第 255 号, 昭和 52 年 5 月を参照。

${ }^{31}$ 建筑部門の議題 2 として、「学生に建築の基本的な修練をさせ、完 成された建築家を養成するのに、いかなる教育、教育法、機関が 必要であるかの探求」が掲げられた。Atti del Primo Congresso degli ingegneri ed architetti italiani in Milano, TIPOG. E LITOG. Degli Ingegneri, Milano, 1873, pp.49-50

${ }^{32}$ Professore di Disegno Architettonico

${ }^{33}$ 確かに、ミラノ近郊に水力発電所を設計した G.モレッティ (Gaetano Moretti, 1860-1938)、アール・ヌーヴォー建筑で名声を得 た G.ソンマルーガ(Giuseppe Sommaruga, 1867-1917)等は歴史に名 を残したが、数のうえでは1877年から1904 年までにミラ ノの美術アカデミーの卒業者はわずかに 12 名であった。Fontana, V. : La scuola speciale di architettura(1865-1915), op.cit., p.240 これに対して、同期間に高等技術学校で建策技師の資格を得た人 数を勘定すると 31 名である。Fig.304 Elenco degli architetti civili laureati dal 1865 al 1914 を参照。

${ }^{34}$ Selvafolta, O. : L'Istituto tecnico superiore di Milano, metodi didattici ed ordinamento interno (1863-1914), op.cit., p.112

${ }^{35}$ Boito, C. : Condizioni presenti degli architetti in Italia, Questioni pratichi di Belle Arti, Hoepli, Milano, 1893

${ }^{36}$ Ibid., p. 363

${ }^{37}$ Ibid., pp.353-354

${ }^{38}$ Ibid., p.369

391889 年の学校創立 25 周年記念においてブリオスキは次のよ うに回想している。「近代の建築家に必要な教盖は多様で複雑な ものである。建設者としては、建設科学のほとんどを確実に理解 しなければならず、それによっていまや新たな材料の使用によっ てかつては想像さえされなかったことが可能になっている。芸術 家としては、単に建築装飾、人物像、透視図の有能なデザイナー であるだけでなく、様式や一般建築術に関する歴史的理解がなけ ればならない。今後、建築家はもはや完全な教養を身につけたと いうことにはならない。なぜなら、建物内部のよりふさわしい習 慣に関する教養があるかと思えば、暖房、換気、音響等に関する 教養があるからである。これからの建築家の教育において行わな ければならない目標の多種多様ぶりが、問題の解決をはなはだ困 難にするということは周知のとおりである。」Dei Poli, A. et al. op.cit., p. 142

40 カザーティ法第 53 条は建築専門学校の創設を認めるものだった が、1885年のコッピーノ法によってフィレンツェ、ローマ、 ナポリの美術アカデミーに建築学校が設けられた。しかし、その 後、コッピーノ法は失効し、ミラノにおける高等技術学校の建筑 教育の先進性が評価され、フィレンツェ、ヴェネツィアにおいて 独立の建築学校が創られた。Fontana, V. : op.cit., pp.240-241

${ }^{41}$ Dei Poli, A. et al. : op.cit., p.504-505

後註 本論文は平成 12 年度「文部省科学研究費補助金」の交付に よってまとめられた。記して感謝申し上げたい。 